\title{
GREEN MARKETING: STRATEGY FOR GAINING SUSTAINABLE COMPETITIVE ADVANTAGE IN INDUSTRY 4.0
}

\author{
Ika Purwanti, Muhammad Dzikri Abadi, Umar Yeni Suyanto \\ Sekolah Tinggi Ilmu Ekonomi KH. Ahmad Dahlan Lamongan \\ E-mail: ikapoer2@gmail.com
}

\begin{abstract}
This study would like to explains conceptual green marketing and its role as a source sustainable competitive advantage in industrial revolution 4.0. The environmental issue is a sizzling topic nowadays as almost every country's government and society has started to be more aware of these issues. Plus, there is currently a phenomenon of industrial revolution 4.0 which demands business practices to be more consumer-oriented. Public concern over environmental damage has made marketers know the needs and value of environmentally friendly marketing, namely green marketing. which is a new strength to create a sustainable competitive advantage. This study is a library research gathering and analyzing information from related references and theories, which have become the basic foundation and sources in analyzing problems in this research. This study seeks to offer Green Marketing ideas as the latest approach in dealing with various business threats. The results show that green marketing able to encourage companies to prepare themselves faster and better, the definition of green marketing has changed over time according to the growing relevance of environmental sustainability.
\end{abstract}

Keywords: green marketing, green marketing mix, green marketing strategy, sustainable competitive advantage

\section{INTRODUCTION}

The issue of environmental preservation has recently become an important concern for the whole world along with the many problems that will threaten the human environment, such as environmental pollution, air pollution, greenhouse effect, global warming, narrowing of tropical rain lands, various waste problems, and threats other threats, which in turn have an impact on human health and survival. Data shows that in the last 50 years, $60 \%$ of the earth's ecosystems have been depleted and natural resource consumption is expected to increase three to six times by 2050 . While the population is expected to reach more than 9 billion people in 2050 (Navyar, 2016). Plus, there is currently a phenomenon of the fourth industrial revolution which demands business practices to be more consumer-oriented. The era of marketers in the fourth industrial revolution marked an increasingly flattering interaction between 
producers and consumers. This is phal citation by cyber technology which will break down the barrier between producers and consumers, because communication between them will occur directly. The results of research conducted by Muller, et al. (2018) found that strategic opportunities, operational factors, social and environmental factors were positive drivers of the implementation of the fourth industrial revolution.

Related to the position of consumers who are crucial in the era of the industrial revolution 4.0, understanding the marketing aspects and consumer behaviour is very important. The marketing concept focuses on business activities and social processes carried out by individuals and groups to get what they need and want through the free creation, offering, and exchange of products and services that have value for customers (Kotler and Keller, 2016). Based on this concept, as an effort to overcome the various threats mentioned above, a market/ producer approach is proposed through Green Marketing.

In essence, green marketing must preserve the environment, that is, companies must use materials that do not damage the environment in each stage of the production activities undertaken. Handoko, et al. (2012) suggested that the role of green marketing in industry revolution 4.0 is as an alternative in efforts to build a positive image of the company, closeness to customers, sustainable competitive advantage, and towards a better standard of living of consumers. As stated by Grant (2008) that if marketers and customers in exchange get a greater value, then both parties feel a greater benefit as well so that an increase in social welfare.

Regarding green consumerism, recently the campaign to stop the use of plastic straws has been increasingly encouraged. Data collected by Divers Clean Action estimates that the use of plastic straws in Indonesia every day reaches 93,244,847 sticks. When stretched, the distance of tens of millions of plastic straws is the same as five trips from Jakarta to Papua (Pratiwi, 2018). Likewise with the Indonesian Minister of Maritime Affairs, Sisu Pudjiastuti, made a call to stop using plastic straws, because it could endanger the ecosystem in the sea and the survival of the animals in it (Movanita, 2018).

This study aims to analyze the role of green marketing analysis in creating sustainable competitive advantage in industry 4.0 era. Developing environmental initiatives at the operational, managerial, and functional levels might contribute to minimizing the cost of production (Hörisch \& Schaltegger, 2019) and to increase the positive image and reputation of the company in external markets (Sharma \& Sharma, 2019).

\section{LITERATURE REVIEW}

As the global competition becomes increasingly fierce, how to sustain competitive advantage or achieve sustainable competitive 
advantage starts obtaining more attention. A corporate is said to have sustainable competitive advantage when the existed or potential competitors can not duplicate or it will cost much to imitate (Dirisu et al., 2013).

\section{Sustainable competitive} advantage refers to value creation in which a firm pursues high innovation by driving market orientation (Kuncoro and Suriani, 2018). During value co-creation while following trends such as digitalization and more critical consumers in selecting a product demand corporates to be more innovative in producing their products, product success will lead to its market performance. This is where a product will be considered by consumers, whether the products have community peace and solution services. The implication is that each corporate which competes in an industry must have a competitive strategy, their application or implicity. Actually, competitive strategy is based on developing general formulas about how marketing activities are able to create consumer satisfaction that should not interfere with public welfare (green marketing) (Arseculeratne and Yazdanifard, 2014; Moravcikova et al., 2017).

Barney and Hesterly (2006) distinguished two types of competitive advantage: temporary and sustainable competitive advantage. According to them, competitive advantage typically results in high profits, but these profits attract competition, and competition limits the duration of competitive advantage in most cases, therefore most competitive advantage is temporary. On the other hand, some competitive advantages are sustainable if competitors are unable to imitate the source of advantage or if no one conceives of a better offering (David, 2009).

At the organizational level, to be able to compete sustainably in a globalized world and be adaptive to changes in the era of the industrial revolution 4.0, organizations must have resources that can create value for organizations that contain four characteristics: valuable resources, rare resources, imperfectly imitable resources, non-substitutability (Purwanti \& Mu'ah, Pengaruh Intangible Asset terhadap Kinerja Keuangan dengan Mediasi Keunggulan Bersaing, 2019). A corporate is said to have sustainable competitive advantage when the existed or potential competitors can not duplicate or it will cost much to imitate Considering all those definitions, there are four points that can be extracted. First, the subjects of sustainable competitive advantage are resources and skills according to resource based view (Barney, 1991; Madhani, 2010). Second, the media of sustainable competitive advantage is competency or capability (Purwanti, Noermijati, \& Rahayu, 2017).

The vital issue is how to transform the subjects of sustainable competitive advantage into the media (Bharadwaj, et al., 1993; Assauri, 2016). Thirdly, the objectives for 
sustainable competitive advantage to achieve can be in forms of financial returns in accounting viewpoint, or capability gaps, or the value protection part in the value chain viewpoint, or customer recognition from business operation field (Kak and Sushil, 2002; Lohmann et al., 2019; Maury, 2018).

A firm's success in using the resources of their organization to meet the demands of their customers in comparison to their competitors is how you measure competitive advantage. In the slow growth and competitive markets, strategic senior managers put their main focus on attaining a competitive advantage (Mahdi and Almsafir, 2014). This is the characterization of numerous modern day business and scholars has been the causes of competitive advantage (Prahalad and Hamel, 1990; Barney and Clark, 2007).

With all of this study's definition, four important points can be looked at closely: subjects, media, objective, and updating. The basic principle of sustainable competitive advantage and its pocess can be constructed from these four elements in Figure 1 (Mahdi and Almsafir, 2014).

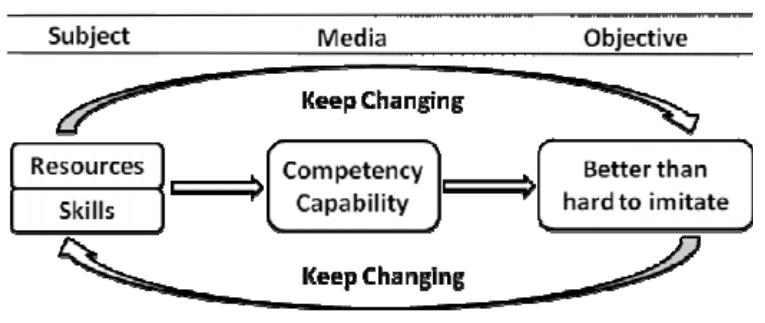

Figure 1. The Process of Sustaining Competitive Advantage
During the past decades, many concepts about the environment emerged such as global warming or greenhouse effect, and greenhouse gases among others. These established a vital concern to respond to critical issues that arose from world-wide climate change and natural resource conservation (Osman et al., 2016). The challenges of global warming have led nations and people develop high concern for environmental protection and as a result, a new format of business has emerged known as Green Business. The industries who claim that they are environment friendly and have concern for society are known as green industries, their marketing philosophy is termed as green marketing and their environment friendly products are known as green products (Saxena and Khandelwal, 2010).

As human wants and needs become unlimited, resources are becoming limited therefore, it is important for marketers to utilize the resources efficiently without waste so as to achieve organizational objectives. Consumers all over the world are becoming concerned about the environment and are changing their behavior with regard to product purchase, consumption and disposal. As a result of this, green marketing has become inevitable with regard to the growing markets for sustainable and socially responsible products and services (Papadas et al., 2019).

The evolution of green marketing has been discussed based on three phases. The first phase 
termed as "Ecological" green marketing, in which all marketing activities were concerned with environment problems and to provide remedies for environmental problems. The focus is on specific environmental problems (such as air pollution or natural resource depletion) and industries (Ottman, 1993). The Second phase was "Environmental" Green Marketing with focus on clean technology that involved designing of innovative new products, which take care of pollution and waste issues. This phase is characterized by the recognition that companies' socioenvironmental performance may lead to competitive advantage and by the awareness of broader global problems, such as biodiversity loss, proverty, and climate change (Peattie, 2001). Third phase was "Sustainable" green marketing, where it has become essential for companies to produce environmentally friendly products as the awareness for such products is on the rise as customers are demanding eco-friendly products and technologies (Peattie, 2001). Marketers in the third phase of green marketing should seek to meet the full environmental costs of production and consumption to create a sustainable economy (Peattie, 2001).

Sustainable marketing can help companies to adopt a long term perspective and value continuity profit, so contributing to find tradeoffs between business objectives and environmental issues.
Laheri et al. (2014) analysed the concept sustainability marketing, highlighting that the initial concept of ecological marketing developed into green, greener, and sustainability.

At present, concepts such as green, sustainable or organic marketing are becoming more widely used, reflecting the growing interest of society in the impact of growing consumption on the environment (Choudri et al., 2016). Organic marketing is the study of the positive and negative aspects of marketing activities on pollution, energy consumption and non-energy consumption Bachanová et al., 2009). This definition includes the following features: green marketing as a subset of the overall marketing activity examines positive and negative activities, and only a limited range of environmental issues (Moravcikova, et al., 2017).

The concept of green marketing is basically a corporate goal regarding profitability and getting better business performance. This concept emphasizes the importance of utilizing ecological issues or environmental preservation in the preparation of marketing mix, and aspects caused by the characteristics of millennial consumers, such as quality of service received, perceived value, impact on the environment, and availability of information as determinants in purchasing (Pappas et al., 2018).

Ginsberg and Bloom (2004) wrote an article describing that various green marketing strategies 
were made based on market segment variables and the company's ability relative to its competitors, including lean green, defensive green, shaded green, and extreme green. The four strategies are then applied to the marketing mix concept. This article also reveals the division of consumers based on their concern for the environment. Furthermore, Peattie and Crane (2005) wrote articles reviewing the history of green marketing since the early 1990s and presented criticisms of the theory and practice of marketing strategies that are environmentally oriented. The research findings explain that what is meant by green marketing in general is only a philosophy. This study discusses five types of green marketing in detail, namely green spinning, green selling, green harvesting, environmental marketing, and compliance marketing. as for the existence of a book by John Grant (2007) entitled "The Green Marketing Manifesto" makes the business world's sensitivity to the environment even higher. This change raises challenges that must be answered for the company, which can be opportunities or threats. Smart companies will view environmental issues as opportunities to satisfy the needs and desires of consumers, not threats. Companies will apply environmental issues in the marketing activities they do, giving rise to new phenomena in the marketing world in the form of the concept of green marketing.

One of the problems that emerged with the development of the concept of green marketing is the public consensus on the understanding of green, as stated by Joel Makower, one of the authors of the green marketing book, that there is no satisfactory definition for "how good is good enough" when a product or company do green marketing claims. The statement indicates that the development of the concept of green marketing will also continue along with the development of issues and facts relating to the global environment, such as issues of climate change, global warming, and even changes in the fourth marketing philosophy. The development of the concept was also triggered by the growing consumer awareness of environmental issues, which ultimately led to the emergence of the concept of green consumer.

Other conceptualizations include: 1) A comprehensive new marketing approach consisting of designing, promoting, and distributing environmentally friendly products to meet the needs of stakeholders imbued with social values (Crassous and Gassmann. 2012); 2) Positive marketing actions aimed at creating value for the company, consumers, and the wider community (Gopaldas, 2015).

The above opinion opposes the old assumptions, beliefs, and traditions and encourages new ways of thinking, that marketers' consideration refers to the marketing managerial process that considers the needs, desires, and goals of customers in a profitable and sustainable manner. The difference 
between traditional marketing and green marketing is explained in Table 1 below.

Table 1. Differences between Traditional Marketing and Green Marketing

\begin{tabular}{|c|c|c|}
\hline $\begin{array}{l}\text { Distinguishing } \\
\text { Factor }\end{array}$ & $\begin{array}{l}\text { Traditional } \\
\text { Marketing }\end{array}$ & Green Marketing \\
\hline $\begin{array}{l}\text { The party that } \\
\text { involved }\end{array}$ & $\begin{array}{l}\text { Companies and } \\
\text { consumers }\end{array}$ & $\begin{array}{l}\text { Companies, } \\
\text { consumers and the } \\
\text { environment }\end{array}$ \\
\hline Goal & $\begin{array}{l}\text { 1. Customer } \\
\text { satisfaction } \\
\text { 2. Satisfaction of } \\
\text { the company's } \\
\text { goals }\end{array}$ & $\begin{array}{l}\text { 1. Customer } \\
\text { satisfaction } \\
\text { 2. Satisfaction of } \\
\text { achieving company } \\
\text { goals } \\
\text { 3. Minimizing the } \\
\text { ecological impact } \\
\text { 4. Social welfare }\end{array}$ \\
\hline $\begin{array}{l}\text { Corporate } \\
\text { responsibility }\end{array}$ & $\begin{array}{l}\text { Economic } \\
\text { responsibility }\end{array}$ & Social responsibility \\
\hline $\begin{array}{l}\text { The reach of } \\
\text { marketing } \\
\text { decisions }\end{array}$ & $\begin{array}{l}\text { The process } \\
\text { from } \\
\text { manufacturing } \\
\text { to product use }\end{array}$ & $\begin{array}{l}\text { The entire product } \\
\text { value chain from the } \\
\text { acquisition of raw } \\
\text { materials to post- } \\
\text { consumption }\end{array}$ \\
\hline Orientation & $\begin{array}{l}\text { Orientation on } \\
\text { product } \\
\text { characteristics }\end{array}$ & $\begin{array}{l}\text { Orientation on the } \\
\text { benefits and value of } \\
\text { the product }\end{array}$ \\
\hline Timescale & Short-term & Long-term \\
\hline $\begin{array}{l}\text { Commitment } \\
\text { to consumers }\end{array}$ & $\begin{array}{l}\text { limited } \\
\text { commitment }\end{array}$ & High commitment \\
\hline Quality & $\begin{array}{l}\text { Quality is the } \\
\text { business of } \\
\text { operations }\end{array}$ & $\begin{array}{l}\text { Quality is the } \\
\text { business of all } \\
\text { departments / people }\end{array}$ \\
\hline
\end{tabular}

Table 1 above shows that there are important differences in the way of thinking between traditional and green marketing. Implementing a green marketing philosophy cannot be achieved only by forming a marketing department to implement green marketing techniques. An orientation to the environment and social welfare needs to include all elements in the organization. The main goal of green marketing is to find the life time value of the customer, after the value is obtained then the next goal, how the value of each group of customers can continue to be enlarged from year to year. After that, how to use the profits obtained from these main objectives, namely to get new customers at a relatively low cost. So the long-term goal is to generate sustainable profits from two groups of customers, namely current customers and new customers. The company's marketing activities initiative must be carried out by prioritizing the community and efforts to create consumer satisfaction must not interfere with the welfare and peace of the community, companies must use materials that do not damage the environment in every stage of production activities undertaken.

Green Marketing Mix os marketing activities that refer to green values are reflected in the implementation of $4 \mathrm{P}$ greens, namely green products, green prices, green places, and green promotions.

Green Product: If we look at it from the product side, marketers or companies must offer ecological products that prioritize long-term security for their users and the environment, are not wasteful of resources, do not produce excessive waste, and do not involve cruelty to animals (Istantia, Kumadi, and Hifayat 2016). The quality of green products must be valuable and perceivable, because otherwise the company will be seen as a failure in sales (Dangelico and Vocalelli, 2017). Mishra and Sharma (2012) in their research stated that green 
products emphasize the direct and tangible benefits provided by environmentally friendly designs, reduce, reuse, recycle, more durable, repairable, compostable, healthy and safer in shipment. Thus, green products must consider environmental aspects in the product life cycle so as to minimize negative impacts on nature and humans.

Green Price: Consumers perceive prices of green products to be relatively higher than prices of traditional products. Most consumers are willing to pay a premium price if there is an additional perception in the product (Dangelico and Vocalelli, 2017). This increase in value can be caused by performance, function, design, attractive shape or taste matching, the superiority of the environment also influences and can be a determining factor between value and quality. In general products, falling prices can increase sales, whereas in products that carry a prestigious image (green products), price increases will increase sales because products with high prices will show one's achievement (Singh, 2012).

Green Place: Green place is related to distribution, from production to consumption, and logistics reserves (Mishra and Sharma, 2012). Green products which are to be delivered from the point of producers to the point of ultimate green consumers. The choice of where and when to make a product always available can have a significant impact on customers. As much as possible the choice of location is distinguished from competitors, by making attractive displays using recyclable materials to emphasize environmental and other advantages. The firm should choose a proper channel of distribution considering product characteristics, consumer characteristics and market characteristics (Wahab, 2018).

Green Promotion: Papadas, et al. (2017) claim that the successful implementation of green marketing depends on good communication (promotion / advertising), because it is very important to educate and empower consumers. Firms should focus more on "Green Advertising" in order to communicate to its green customers (who use eco-friendly products) and as well as traditional customers (who are not green users) about the concept of environmental protection. Firms should have special sales promotion for eco friendly products such as coupons, cash refunds, and offers etc to attract consumers. If this works well, the customer will make a purchase either by switching brands / products (switching) or staying with the same brand / product. The types of green marketing ads that are used are advertisements that display the company's image and its responsibility towards the environment, promoting a green lifestyle by highlighting a product and service (Sabre and Siglo, 2014; Nandini, 2016). The characteristics of the green marketing mix are summarized in Table 2 below. 
Table 2. Characteristics of Green

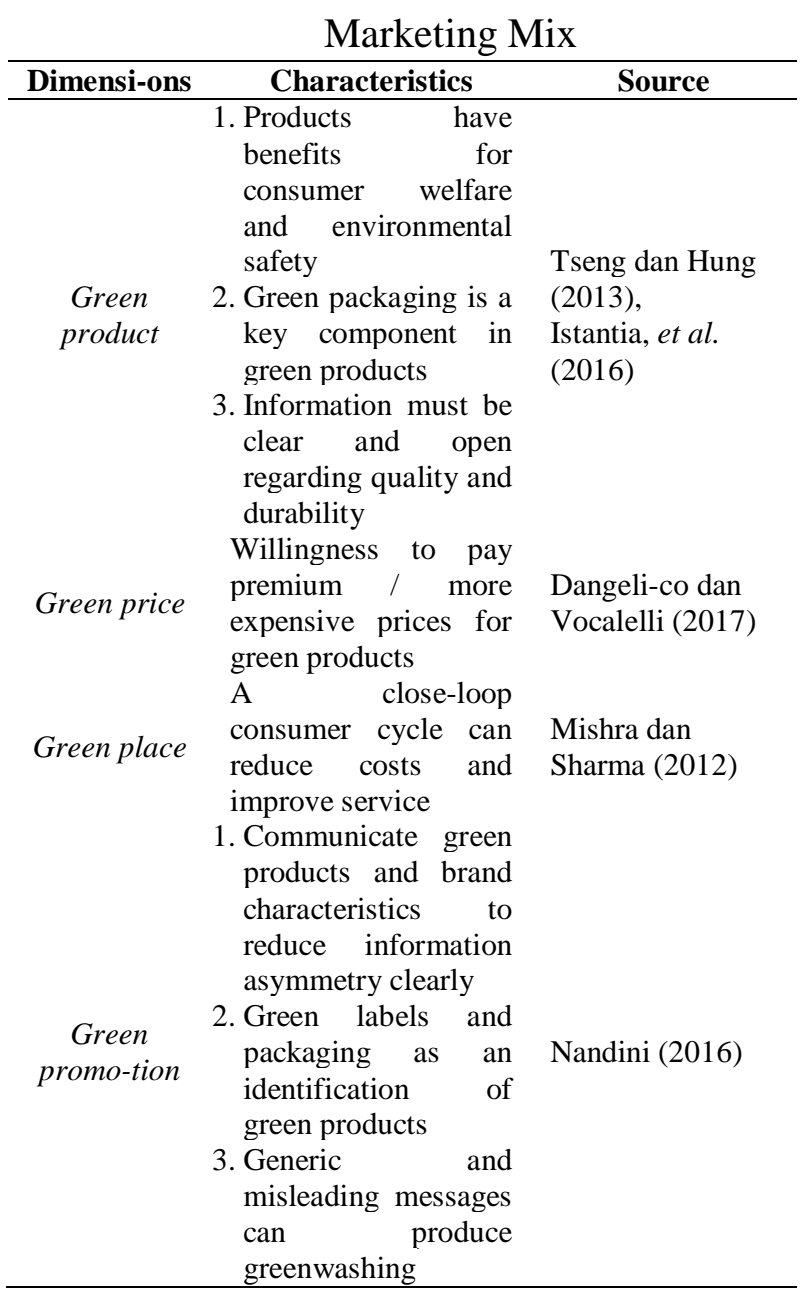

Green Marketing Strategy, a holistically conceived strategy must also implementation of green marketing goals into business plans (Moravcikova et al., 2017). Green marketing, as well as traditional marketing, carries two great themes: marketing mix and marketing strategy. Marketing strategy is a continuous cycle in which individual STP process sequences: segmentation, target market selection, and positioning are conducive to competitive advantage (Asha'Ari, 2017). According to Kotler and Amstrong (2014), marketing strategy entails four different steps: segmentation, targeting, positioning, and differentiation. In the following, the characteristics of each stepsfor green marketing strategy will be analysed.

Through segmentation and targeting, a company identifies the groups of consumers to serve. An analysis of reviewed studies highlighted that, in the green marketing domain, there are two main approaches for segmenting consumers: according to consumers's characteristics or according to purchase's ones (Dangelico and Volacelli, 2017).

When the purchase needs a high degree of confidence, the company should reduce information asymmetries and encourage consumers, when a high compromise is required, the firm should improve its efficiency, so to reduce costs. In this way, consumers could be segmented by "why" they buy instead of "who" buy what. The results of D'souza et al. (2006) of this segmentation lead to the four clusters of consumer generations: conventional consumers (non green consumers not perceiving benefits of the green purchase and adopting an unconscious approach), emerging green consumers (consumers that recognize the benefits of green products, but may not be motivated to purchase them), price sensitive green consumers (consumers aware of environmental labels, but unwilling to pay the perceived higher price), and environmentally green consumers (environmentally 
concerned and ready to buy green products when they can). The greaters is the perception of benefits and the search for information, the greener is consumer.

Rex and Bauman (2007) highlighted that green marketing target should be: from targeting green consumers with green products to broadening the targeted consumers by including green features as aone of the many characteristics of a product. Laroche et al. (2001), targeting based on demographic analyses, found that married women with children represent the most environmentally friendly segment. Based on this, the authors highlighted that marketers may target tis segment as their prime target. Nyilasy \& Gangadharbatla (2015) suggested that technological tools, such as internet, can be help companies to better target green consumers. The authors provided examples of green targeting actions available for firms, distinguished in tactical (advertisements in green focus media, mentioning green features of products), quasi-strategic (developing a green brand in addition to existing brands), and strategic (launching a new green strategic business unit).

Positioning and Differentiation. In fact, consumers tend to buy green products from green companies. It is not simple to make ethical values and marketing walk together, but investing resources to increase green perceived value could have positive effects on green purchase intentions and green trust (Chen and Chang,
2012), that is also boosted by green brand image and leads to a higher green brand equity (Chen, 2010). D'souza et al. (2013) suggested the positioning strategies that communicate green marketing mix elements can strengthen corporate reputation.

The green brand can be positioned through various attributes that will contribute to differentiate it from competitors. Positioning can be based on functional or emotional product attributes (Schmuck et al., 2018). A positioning strategy based on functional product attributes can be enhanced by environmental benefits coming from production processes or product usage. Aaker (1996), strategies strictly based on the functional characteristics of the product could have some disadvantages: they can be easily imitated, assume that the consumer only act in a rational way, can reduce flexibility or brand differentiation. Osman et al. (2016) suggested that differentiation strategy of green marketing must satisfy two objectives: improved environmental quality and customer satisfaction. An alternative positioning and differentiation are the emotional, based on three possible types of benefits provided by the brand: a feeling of well-being (warm glow), possibility of expression through consumption of green brand as a status symbol, and benefits arising from sensations and feelings experienced through the contact with nature (Kals et al., 1999). The authors also found that both 
functional and emotional positioning in green marketing have positive effect on brand attitude, however the strongest effect is obtained upon a combination of both types of positioning.

\section{RESEARCH METHOD}

This study is a literature study gathering theoretical references relevant to green marketing and sustainable competitive advantage in industry 4.0. The theoretical references were sought through international and national reputable journals and books that were considered relevant until September 2019. Studies included in the review have been analysed with specific attention to three main topics: definition of green marketing and related concepts, green marketing strategy, and green marketing mix.

\section{RESULT AND DISCUSSION}

The sustainability of the company's existence in the industrial revolution era 4.0 certainly requires marketers with specifications that are superior to previous eras. Marketers strive to create more value from consumers' views of a company's products. Marketers must pay attention to the welfare and peace of the community in marketing their products. Lasi, et al (2014) state that the potential benefits that can be maximized by marketers in industrial revolution are product development becoming faster, realizing individual demand (product customization), production that is flexible and fast in responding to problems and resource efficiency. This is consistent with the statement of Lee, et al. (2013) that marketing in the industrial revolution must be able to meet the needs of individual customers and be able to create value added products. These statements imply that the potential benefits of era 4.0 can be maximized by implementing green marketing that suits current needs.

Green marketing strategy brings about certain benefits to a business which can be harnessed to derived sustainable competitive advantage. The benefits have been the reduction in cost of production and green marketing would be brand loyalty. Studies have proved that consumers attach less importance to brand loyalty in the case of products which carry intrinsic benefits. Green products are held in a different perspective owing to their contribution to the environment.

There develops a spiritual relationship between green products and customer. Study of Harizan and Rahman (2016) show that spirituality imposed a significant positive influence on willingness to purchase green products through its personal, environmental, and communal dimension. The highest influencing factors was communal spirituality. People are thrown into their inner strength to find answer to meaning and purpose in life through spiritual pursuits when engaging with green products. Consumers with high feelings and experiences in personal spirituality tend to behave in a way that matches his or her personal spirituality values. 
The main goal of green marketing is to present consumers with the importance of protecting the environment in the context of product consumption, placing an emphasis on building long-term relationships based on both sides of communication, not only with customers but also with other stakeholders and creating the natural need to be environmentally responsible and does not conflict with the religious norms of consumers. The concept of green marketing offers the idea of shared responsibility in determining prices, with the intention that prices are not just profit margins transferred from buyers to sellers, which in some contexts often have implications for the lack of buyer's bargaining power and strong exploitative efforts, but prices are a joint commitment between the two parties which is built on the basis of the quality of relationship in the form of trust, mutual understanding, cooperation and not opportunistic behaviour.

Many businesses implement green marketing, especially for seasons of opportunity, social and environmental responsibility, pressure from government and competition, and cost reduction. Getting a competitive advantage can be achieved through seven green marketing strategies for understanding the deeper connections between customer and stakeholder, environmental and social values, branding, and proactive business (Moravcikova, 2017).
Once the business wants to gain a sustainable competitive advantage, it must integrate environmental thinking into all aspects of marketing (Choudhory, 2018). This will only be achieved through the implementation of the green marketing mix and green marketing strategy, as the basic prerequisite for future competitive struggle has become the solution of environmental issues and the level of implementation of the principles of green marketing, which will benefit from higher profitability, competitive advantage, improved stakeholder relations and better environmental performance (Moravcikova et al., 2017.

Green marketing is not only an environmental protection tool but also as a marketing strategy. Ottman (2011) states that a green marketing will grow and mature, taking advantage of opportunities will provide opportunities to increase market share in competition. Environmental issues are growing rapidly in the community with global warming. Marketers need to see this phenomenon as one thing that has the potential as a business opportunity. Green marketing strategies began to be implemented, in response to the awareness of products that are sensitive to their environment (Gaikwad and Ingavale, 2011). Based on the analysis of various research results, the role of marketers in managing green marketing can be one of the choices congruent with the marketing 4.0 concept. 


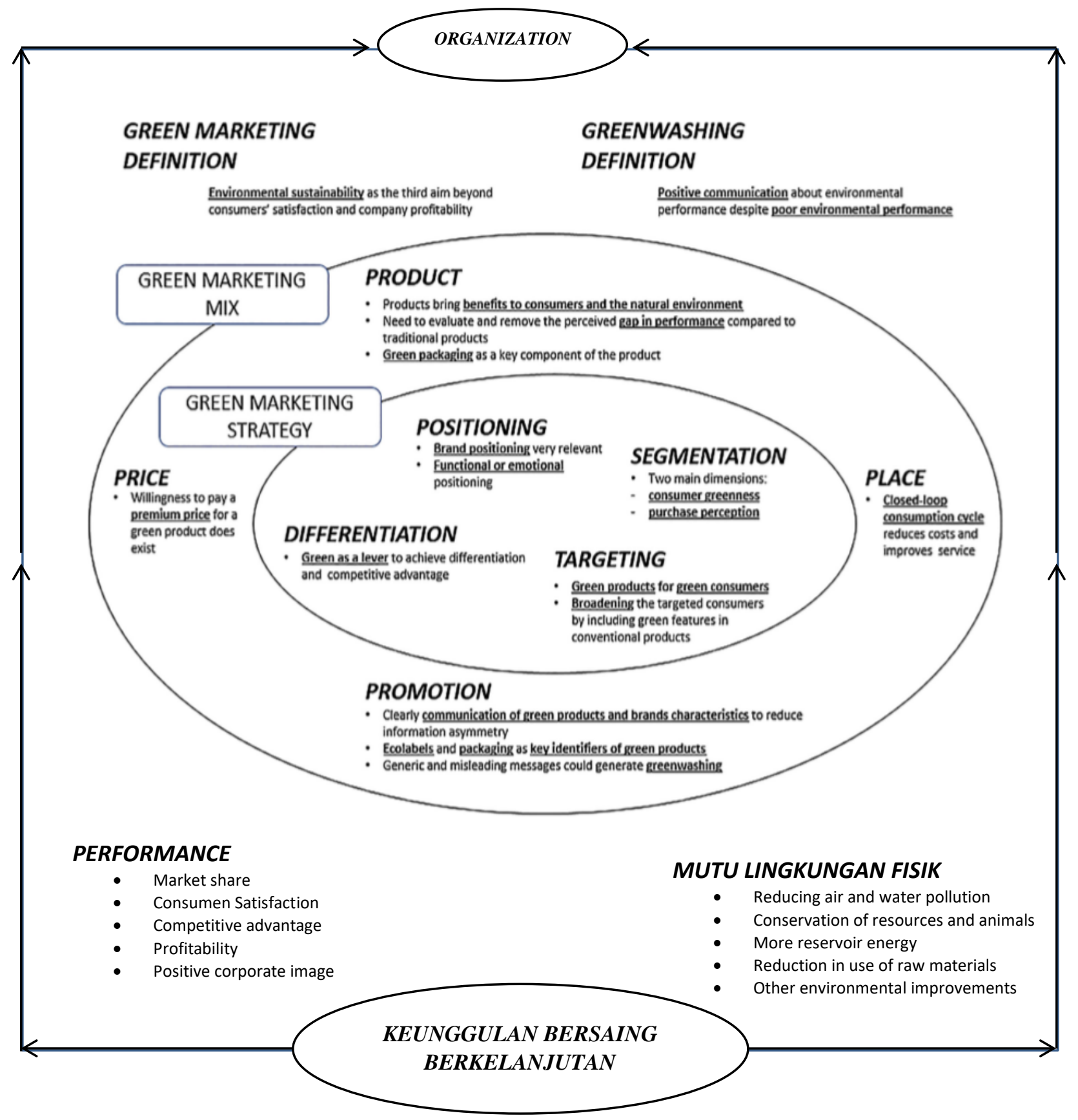

Figure 2. The conceptual of Green Marketing Strategy, Green Marketing Mix, and Sustainable Competitive Advantage (Modified from Kinoti (2011); Dangelico dan Vocaleli (2017)

\section{CONCLUSION}

A key area in each business is the right choice of strategy on which the further development of the business and its position in the market depends. The present is characterized by hyper-competition. On the other hand, it should be noted that there is a combination of phenomena that have a negative impact on the environment with production and consumption itself. 
Sustainability implies that we now have to use all the resources so that we do not rely on the same conditions for future generations.

Environmental sustainability is not just a matter of compliance to protect natural resources. The challenge to achieve development sustainability over the coming decades requires radical changes in all production and consumption in industrial societies. In line with business demands that increasingly recognize the many competitive advantages and business opportunities that can be obtained from eco-sustainability and green marketing, the world shows evidence that many people worry about the environment and change their buying behaviour. As a result, there is sustainable market growth and socially responsible products and services. The types of businesses that are available as well as the products they produce show that the marketing

\section{REFERENCES}

Aaker, D.A. (1996) Measuring Brand Equity across Products and Markets. California Management Review, 38, 102-120.

Arseculeratne, D., \& Yazdanifard, R. (2013). How Green Marketing Can Create a Sustainable Competitive Advantage for a Business. International Business Research, 7(1).

Asha'Ari,M.J., Daud,S.(2017). The effect of green growth strategy on corporate sustainability approach is changing. People generally want to do the right thing, so the challenge and opportunity for green marketers is to make it easy for people to do it. when all the samequality, price, performance then the benefits of environmentalavailability will most likely give tips for getting an environmentally friendly product.

This paper has supported marketing as well as other functional areas of business contributing to environmental problems that support the world today. It has a role in finding solutions to these environmental problems. This paper is more about marketing through green marketing and specifically green marketing strategies addressing challenges with positive results from improving organizational performance, better physical environment. It will eventually lead to the development of maintenance towards sustainable competitive advantage.

performance. Adv. Sci. Lett., 23, 8668-8674

Assauri, S. (2016). Strategic Management Sustainable Competitive Advantages. PT Raja Grafindo Persada. Jakarta.

Bachanová, P., Corejová, T., \& Rostášová, M. (2009). The green issues of postal industry in Europe. 901-905.

Barney, J. (1991) Firm Resources and Sustained Competitive Advantage. Journal of Management, 17, 99120.

Barney. J.B dan Clark, D.N. (2007). Resource-Based Theory: Creating 
and Sustaining Competitive Advantage. Oxford University Press. Oxford.

Barney, J. B., \& Hesterly, W. S. (2006). Strategic Management and Competitive Advantage: Concepts and Cases. Pearson: Harlow.

Bharadwaj, S.G., Varadarajan, P.R., Fahy, J. (1993). Sustainable Competitive Advantage in Service Industries: A Conceptual Model and Research Propositions. Journal of Marketing 57: 83-9.

Chen, Y. S. (2010). The Driver of Green Brand Equity: Green Brand Image, Green Statisfaction, and Green Trust. Journal of Business Ethics 9 (3): pp: 307-319.

Chen, Y. S., \& Chang, C. H. (2012). Enhance green purchase intentions: The roles of green perceived value, green perceived risk, and green trust. Journal of Management Decision, 50(3), 502-520.

Choudhury, D.P. (2018). Sustainability Management. Zorba Books, India.

Choudri, B. S., Baawain, M., Al-Zeidi, K., Al-Nofli, H., Al-Busaidi, R., \& Al-Fazari, K. (2016). Citizen perception on environmental responsibility of the corporate sector in rural areas. Environment, Development and Sustainability, 1-12.

Crassous, T., \& Gassmann, J. (2012). Gaining Competitive Advantage Through Green Marketing: How green marketing is used as a competitive advantage?

David, F.R. (2009). Manajemen Strategis. Salemba Empat: Jakarta.

Dangelico, R. M., \& Vocalelli, D. (2017). "Green Marketing": An analysis of definitions, strategy steps, and tools through a systematic review of the literature. Journal of Cleaner Production, 165, 1263-1279.

Dirisu, J. I., Iyiola, O., \& Ibidunni, O. S. (2013). Product Differentiation: A tool of competitive advantage and optimal organizational performance (A study of Unilever Nigeria PLC). European Scientific Journal, 9(34), 258-281.

D’souza, C., Mehdi, T., Sullivan-Mort, G. (2013). Environmentally Motivated Actions Influencing Perceptions of Environmental Corporate Reputation. Journal of Strategic Management, 21, 541555.

Gaikwad, A., and Ingavale, D. (2011). A Study of Consumer Awareness for Green Marketing. National conference on Business strategies for Emerging Markets.

Ginsberg, J. M., \& Bloom, P. N. (2004). Choosing the right green marketing strategy: green marketing has not fulfilled its initial promise, but companies can take a more effective approach if they realize that a one-size-fits-all strategy does not exist. MIT Sloan Management Review, 46(1), 79+.

Gopaldas, A. (2015). Creating firm, customer, and societal value: Toward a theory of positive marketing. Journal of Business Research, 68(12), 2446-2451. https://doi.org/10.1016/j.jbusres.2 015.06.031

Grant, J. (2007). The green marketing manifesto. Chichester: John Wiley $\&$ Sons. Available online at

Grant, J. (2008). Green Marketing. Strategic Direction, 24 (6). Pp. 25 $-27$.

Handoko, T. H., Indarti, N., dan Almahendra, R. (2012). Manajemen dalam Berbagai Perspektif. Penerbit Erlangga. Jakarta. 
Harizan, S. H., Afezah, W., \& Abdul, W. (2017). Spirituality of Green Purchase Behavior: Does Religious Segmentation Matter? Spirituality of Green Purchase Behavior: Does Religious Segmentation Matter? October.

Hörisch, J., Freeman, R. E., \& Schaltegger, S. (2014). Organization \& Environment. https://doi.org/10.1177/108602661 4535786

Istantia, S., Kumadji, S., \& Hidayat, K. (2016). Pengaruh Green Marketing Terhadap Citra Merek Dan Keputusan Pembelian (Survei pada Pengguna Produk Ramah Lingkungan Lampu Philips LED di Perum Kepanjen Permai 1, RW 4, Desa Talangagung, Kec. Kepanjen, Malang, Jawa Timur). Jurnal Administrasi Bisnis S1 Universitas Brawijaya, 32(1), 174-182.

Kak, A., \& Sushil, H. (2002). Sustainable competitive advantage with core competencies: A review. Global Journal of flexible systems management, 3(4), 23-38.

Kals, E., Schumacher, D., Montada, L. 1999. Emotional Affinity toward Motivation Basis to Protect Nature. Environmental Behaviour, 31, 178-202.

Kinoti, M. W. (2011). Green marketing intervention strategies and sustainable development: A conceptual paper. International Journal of Business and Social Science, pg2(23)

Kotler, P. and Amstrong, G. (2014). Principles of Marketing, 12th Edition, Jilid 1 Terjemahan Bob Sabran Jakarta : Erlangga.

Kotler, P. and Keller, K.L. (2012). Marketing Management, Edisi 14, New Jersey: Prentice-Hall Published.

Kuncoro, W., \& Suriani, W. O. (2018). Achieving sustainable competitive advantage through product innovation and market driving. Asia Pacific Management Review, 23(3), 186-192.

Laheri, V. K., Dangi, H., \& Vohra, A. (2014). Green Marketing: Development of Construct and Its Evolution. Asia-Pacific Journal of Management Research and Innovation, 10(2), 147-155.

Laroche, M., Bergeron, J. and BarbaroForleo, G. (2001). Targeting consumers who are willing to pay more for environmentally friendly products. Journal of Consumer Marketing, Vol. 18 No. 6, pp. $503-$

520. https://doi.org/10.1108/EUM 0000000006155

Lasi, H., Fettke, P., Kemper, H.G., Feld, T. dan Hoffmann, M. (2014). Industry 4.0. Business \& Information Systems Engineering, 6(4). Pp. 239.

Lee, J., Lapira, E., Bagheri, B., dan Kao, H., (2013). Recent Advances and Trends in Predictive Manufacturing Systems in Big Data Environment. Manuf. Lett, 1 (1). Pp. 38-41.

Lohmann, S., Lacerda, D. P., Camargo, L. F. R. \& Dresch, A. (2019). Operations strategy and analysis of competitive criteria: a case study of a food business. Gestão \& Produção,

Madhani, P. (2010). Resource Based View (RBV) of Competitive Advantage: An Overview. ... BASED VIEW: CONCEPTS AND PRACTICES, Pankaj ..., March 2010. http://papers.ssrn.com/sol3/papers. cfm?abstract_id $=1578704$

Mahdi, O. R., \& Almsafir, M. K. (2014). The Role of Strategic Leadership in Building Sustainable Competitive Advantage in the Academic Environment. Procedia - Social and Behavioral Sciences, 
129, 289-296. https://doi.org/10.1016/j.sbspro.20 14.03.679

Maury,B. (2018). Sustainable competitive advantage and profitability persistence: Sources versus outcomes for assessing advantage, Journal of Business Research, 84, 100-113.

Mishra, P., Sharma, P. (2012). Green Marketing: Challenges and Opportunities for Business. Journal of Marketing Communication, 8, 35-41.

Moravcikova, D., Krizanova, A., Kliestikova, J., \& Rypakova, M. (2017). Green marketing as the source of the competitive advantage of the business. Sustainability (Switzerland), 9(12), 1-13. https://doi.org/10.3390/su9122218

Movanita, A. N. K. (2018). Menteri Susi: Stop Penggunaan Sedotan Plastik.

https://surabaya.kompas.com/read/ 2018/11/16/160000326/menterisusi--stop-penggunaan-sedotanplastik

Nandini, B. (2016). Green Marketing a Way to Sustainable Development. Anveshana's International Journal Research in Regional Studies, Law, Social Sciences, Journalism and Management, 1 (1), 20-26.

Nayyar, S. (2016). Sustainable consumption and the Fourth Industrial Revolution. https://www.makingitmagazine.ne $\mathrm{t} / \mathrm{p}=9926$

Nyilasy, G., \& Gangadharbatla, H. (2015). How to reach green consumers on the internet? Digital and social media strategies for addressing the environmentally conscious. March

Oliver Müller, Maria Fay \& Jan vom Brocke (2018) The Effect of Big Data and Analytics on Firm
Performance: An Econometric Analysis Considering Industry Characteristics, Journal of Management Information Systems, 35:2, 488-

509, DOI: $\underline{10.1080 / 07421222.201}$ $\underline{8.1451955}$

Osman, A., Othman, Y. H., Salahudin, S. N., \& Abdullah, M. S. (2016). The Awareness and Implementation of Green Concepts in Marketing Mix: A Case of Malaysia. Procedia Economics and Finance, 35(October 2015), 428-433.

Ottman, J.A. (1993). Green Marketing: Challenges and Opportunities. NTC Business Books, Chicago.

Papadas, K. K., Avlonitis, G. J., Carrigan, M., \& Piha, L. (2019). The interplay of strategic and internal green marketing orientation on competitive advantage. Journal of Business Research, 104(July), 632-643. https://doi.org/10.1016/j.jbusres.2 018.07.009

Pappas, I. O., Mikalef, P., Giannakos, M. N., Krogstie, J., \& Lekakos, G. (2018). Big data and business analytics ecosystems: paving the way towards digital transformation and sustainable societies. Information Systems and E-Business Management, 16(3), 479-491.

Peattie, K. (2001). Towards Sustainability: The Third Age of Green Marketing. The Marketing Review, 2(2), 129-146. doi:10.1362/1469347012569869

Peattie, K., \& Crane, A. (2005). Green marketing: Legend, myth, farce or prophesy? Qualitative Market Research: An International Journal, 8(4), 357-370. https://doi.org/10.1108/135227505 10619733

Prahalad, C.K. dan Hamel, G. (1990). The Core Competence of The 
Corporation. Harvard Business Review. pp.1-4.

Purwanti, I., Noermijati., \& Rahayu, M. (2017). Pengaruh Rare Resources terhadap Keunggulan Bersaing dan Kinerja Usaha. MIX: Jurnal Ilmiah Manajemen, 7 (3), 484497.

Purwanti, I., \& . Muah. (2019). Pengaruh Intangible Asset Terhadap Kinerja Keuangan Dengan Keunggulan Bersaing Sebagai Mediasi. Mix: Jurnal Ilmiah Manajemen, 9(1), 72.

Pratiwi, P. I. (2018). Kurangi Sampah Plastik, Restoran di California Batasi Penggunaan Sedotan Plastik. https://kbr.id/intermezzo/092018/kurangi_sampah_plastik_re storan_di_california_batasi_pengg unaan sedotan plastik/97374.htm 1

Qurniawati, R. S. (2017). Theoritical Review: Teori Pemasaran Hijau. Among Marketing, 10(20), 73-84.

Rex, E., Baumann, H. (2007). Beyond Eco Labels: What Green Marketing Can Learn from Conventional Marketing?. Journal of Clean. Prod, 15, 567-576.

Sabre, M. E., \& Siglo, U. (2014). Green advertising in Argentina . An analysis of environmental claims in TV ads. 27-38. https://doi.org/10.7764/cdi.34.54

Saxena, R. \& Khandelwal, P. K. (2010).
Sustainable development through green marketing: The industry perspective, The International Journal of Environmental, Cultural, Economic and Social Sustainability, 6 (6), 59-79.

Schmuck, D., Matthes, J., Naderer, B., \& Beaufort, M. (2018). The Effects of Environmental Brand Attributes and Nature Imagery in Green Advertising The Effects of Environmental Brand Attributes and Nature Imagery in Green Advertising. 4032. https://doi.org/10.1080/17524032.2 017.1308401

Sharma, S., \& Sharma, P. (2019). Organizational Drivers of Corporate Environmental Sustainability Strategy. In Patient Capital: The Role of Family Firms in Sustainable Business (Organizations and the Natural Environment, pp. 98-149). Cambridge: Cambridge University Press.

doi:10.1017/9781316402528.004

Singh, S. (2012). Green Marketing: Challenges and Strategy in The Changing Scenario. International Journal of Advanced Research in Management and Social Sciences, 1 (6). www.garph.co.uk.

Wahab, S. (2018). Sustaining the Environment Through Green Marketing. 7(2), 71-77. 